\title{
Krzysztof Stefański
}

Instytut Historii Sztuki

Uniwersytet Łódzki

http://dx.doi.org/10.18778/2084-851X.06.09

O dziedzictwie poprzemysłowym w Łodzi i na świecie.

25. Konferencja Grupy Roboczej Polskich i Niemieckich Historyków Sztuki i Konserwatorów Miasto postindustrialne i jego dziedzictwo wXXI wieku. Ochrona - konserwacja - rewitalizacja. Łódź, 11-14 października 2017 roku.

W końcówce lat $80 . \mathrm{XX}$ wieku, w trakcie rozmów między grupą polskich i niemieckich historyków sztuki i konserwatorów dzieł sztuki, narodziła się idea stworzenia forum wymiany wiedzy i doświadczeń. Główną rolę w tej inicjatywie odegrali Andrzej Tomaszewski (1934-2010) i Dethard von Winterfeld. W ten sposób powstała Grupa Robocza Polskich i Niemieckich Historyków Sztuki i Konserwatorów.

Podstawową formą spotkań między Polakami i Niemcami stały się konferencje naukowe poruszające kwestie interesujące badaczy po obu stronach Odry i Nysy Łużyckiej. Przyjęto formułę organizowania takich konferencji naprzemiennie, raz w Polsce, raz w Niemczech. Obrady odbywały się w językach niemieckim i polskim, choć akceptowano również angielski. Ich owocem były pokonferencyjne polsko-niemieckie tomy.

Dotychczas spotkania miały miejsce w większości znaczących ośrodków naukowych w Polsce: w Warszawie, Krakowie, Poznaniu, Gdańsku, Lublinie czy Katowicach. Do zeszłego roku Grupa Robocza nie gościła w Łodzi. Może to dziwić, jeśli weźmiemy pod uwagę bogate tradycje wspólistnienia Polaków i Niemców w tym mieście oraz znaczący wpływ kultury i sztuki niemieckiej w okresie intensywnego rozwoju Łodzi przemysłowej. Stąd od dłuższego czasu podejmowano starania, by ten stan zmienić. Rozmowy prowadził autor niniejszego tekstu, reprezentujący Katedrę Historii Sztuki Uniwersytetu Łódzkiego, z dr hab. Beate Störtkuhl z Oldenburga i z prof. Tadeuszem J. Żuchowskim z Poznania. Zakończyły się one sukcesem. Zadecydowała o tym deklaracja dyrektor Centralnego Muzeum Włókiennictwa w Łodzi, Anety Dalbiak, o podjęciu się organizacji konferencji we współpracy z Katedrą Historii Sztuki UŁ oraz Oddziałem Łódzkim Stowarzyszenia Historyków Sztuki. Ważne było również finansowe wsparcie tej inicjatywy przez Urząd Miasta Łodzi. Partnerem ze strony niemieckiej był Uniwersytet Europejski Viadrina we Frankfurcie nad Odrą, a finansowy wkład strony niemieckiej zapewniła dotacja Pełnomocnika Rządu Federalnego Niemiec ds. Kultury i Mediów.

Rezultatem tych działań było zorganizowanie w Łodzi w dniach 11-14 października 2017 roku 25. Konferencji Grupy Roboczej Polskich i Niemieckich Historyków Sztuki i Konserwatorów. Patronat honorowy nad wydarzeniem sprawowali 


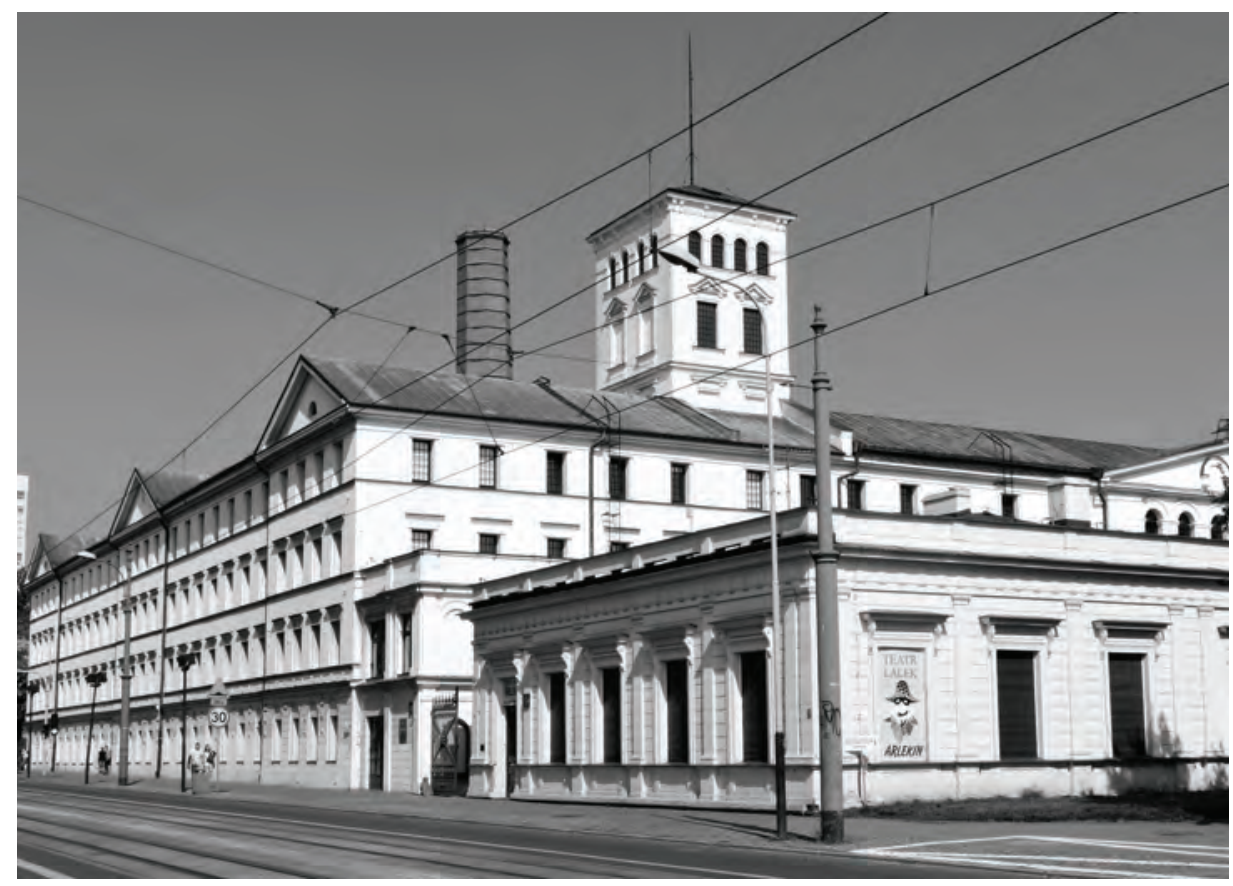

1. Dawna fabryka Ludwika Geyera, obecnie siedziba Centralnego Muzeum Włókiennictwa w Łodzi Fot. K. Stefański

Prezydent Miasta Łodzi, Ambasador Republiki Federalnej Niemiec w Polsce, Narodowy Instytut Dziedzictwa oraz Rektor Uniwersytetu Łódzkiego. Obrady odbywały się w Centralnym Muzeum Włókiennictwa w Łodzi - dawnej fabryce Ludwika Geyera, zwanej „Białą fabryką” - w odrestaurowanych niedawno wnętrzach o industrialnym charakterze. Fakt, że Łódź gościła jubileuszową, 25. konferencję, miał dodatkową wymowę i skłaniał do nadania jej uroczystej oprawy.

Powierzenie Łodzi organizacji konferencji wiązało się z wyborem tematu konferencji - przyjęta formuła spotkań zakłada uwzględnienie specyfiki miejsca i jego tradycji. W toku dyskusji prowadzonych w gronie łódzkich historyków sztuki, m.in. z prof. Piotrem Gryglewskim, prof. Tadeuszem Bernatowiczem, drem Łukaszem Sadowskim, dr Karoliną Stanilewicz i Małgorzatą Markiewicz Wróblewską, zadecydowano, że najbardziej nośną i aktualną dla miasta kwestią jest problem rewitalizacji dziedzictwa poprzemysłowego, mający także szerszy międzynarodowy wymiar. Przyjęto ostatecznie formułę „Miasto postindustrialne i jego dziedzictwo w XXI wieku. Ochrona - konserwacja - rewitalizacja”, która została w pełni zaakceptowana przez naszych niemieckich partnerów.

Temat był w przypadku Łodzi szczególnie aktualny, nie tylko ze względu na olbrzymią wagę problemów związanych z zachowaniem i rewitalizacją poprzemysłowego dziedzictwa miasta. Przypomnieć trzeba bowiem, że w 2017 roku Łódź starała się o organizację wystawy International Expo 2022 (tzw. Małe Expo) właśnie pod hasłem rewitalizacji: „City Re:Invented”. Wprawdzie kilka tygodni później jako 


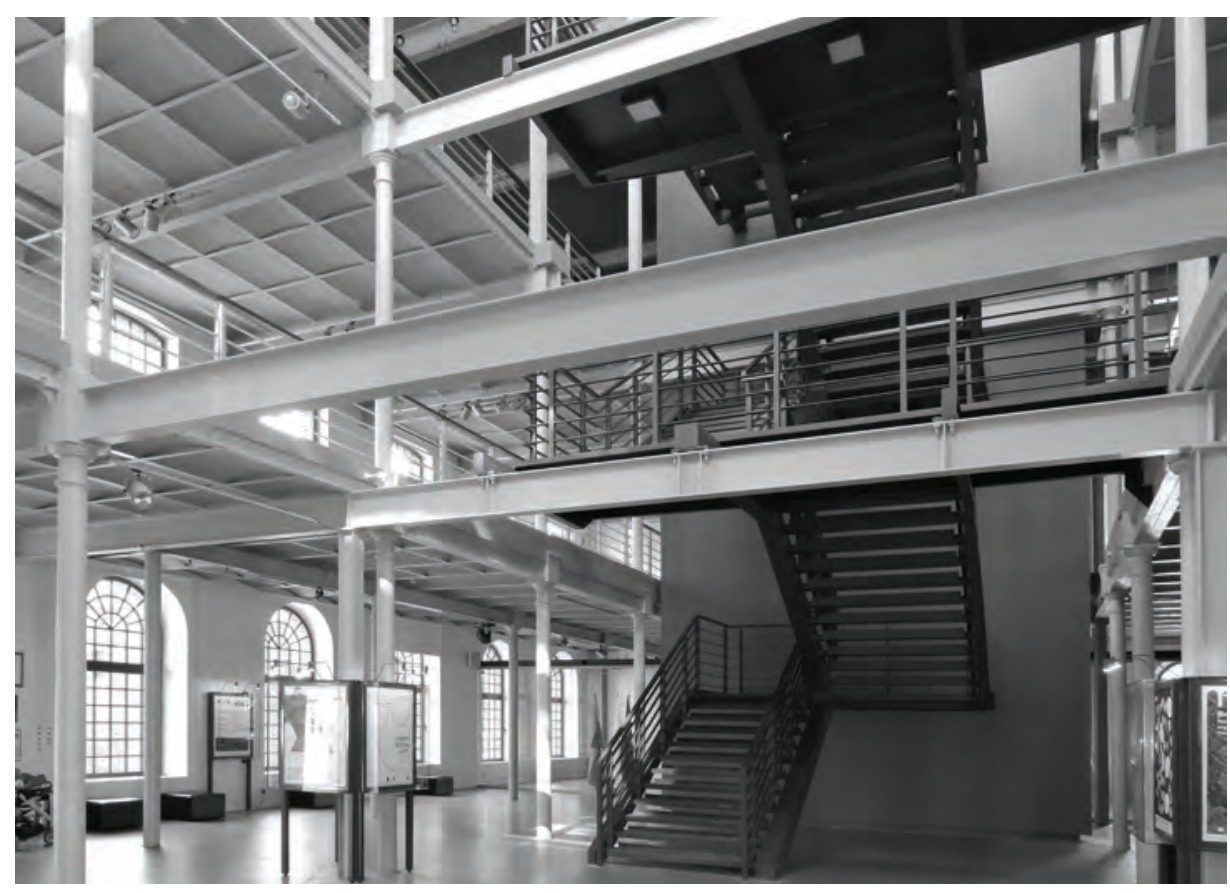

2. Dawna fabryka Ludwika Geyera, obecnie siedziba Centralnego Muzeum Włókiennictwa w Łodzi - wnętrze skrzydła wschodniego, miejsce obrad konferencji. Fot. K. Stefański

przyszłego organizatora Expo wybrano argentyńskie Buenos Aires, ale zaproponowana przez Łódź tematyka spotkała się z dużym zainteresowaniem.

Problematyka łódzkiej konferencji spotkała się szerokim odzewem ze strony badaczy z wielu krajów. Nadeszło około 30 zgłoszeń. Ograniczony czas obrad sprawił, że część z nich nie mogła zostać przyjęta. Ostatecznie w trakcie dwóch dni obrad wygłoszono 17 referatów i 6 komunikatów zaprezentowanych przez gości z Polski, Niemiec, Szwajcarii i Estonii. Wszystkie referaty wygłaszane w ciągu dwóch dni ujęto w pięć sesji tematycznych, a krótsze, dziesięciominutowe komunikaty w dwa bloki. Pierwszą z sekcji - „Miasto przemysłowe jako kulturowe dziedzictwo - kwestie teoretyczne" - poprowadził prof. Tomasz Torbus, a wypełniły ją wystąpienia dra Waldemara J. Affelta, zespołu kierowanego przez prof. Bogusława Szmygina oraz dra Piotra Gerbera, tworzące teoretyczne wprowadzenie do tematyki konferencji. Kolejną sekcję: „Wyzwania wielkich okręgów przemysłowych”, moderowała dr hab. Beate Störtkuhl. W jej trakcie wygłoszone zostały referaty dr hab. Irmy Koziny, dra Thomasa Parenta czy dra Matthiasa Baxmanna, obejmujące szersze aspekty związane z kwestią cywilizacji przemysłowej.

Tematykę kolejnego panelu określa dobitnie jego tytuł: „Doświadczenia niemieckie. Pośrednictwo - waloryzacja postindustrialnego dziedzictwa przemysłowego: koncepcje i strategie", a poprowadził go prof. Tadeusz J. Żuchowski. Dopełnieniem tego dnia był uroczysty wykład wieczorny (Abendvortrag) jednej z założycielek Grupy Roboczej Polskich i Niemieckich Historyków Sztuki i Konserwatorów, 
prof. Ewy Chojeckiej z Katowic/Bielska Białej, pt. Obraz „Wielkiej Industrii” - przedmiot rozważań historyka sztuki (Thomas Voßbeck i Michael Baxandall). Następnie prof. Wojciech Bałus z Krakowa i dr Dietmar Popp z Marburga zaprezentowali nowo wydany drugi tom serii Dehio - Handbuch der Kunstdenkmäler in Polen pod tytułem Zabytki sztuki w Polsce. Małopolska, będący dużym osiągnięciem naukowym i świadectwem owocnej współpracy polskich i niemieckich historyków sztuki.

W drugim dniu konferencji, w trakcie panelu „Wyzwania wobec zachowania i rewitalizacji dziedzictwa postindustrialnego", moderowanego przez prof. Tadeusza Bernatowicza, krąg zagadnień rozszerzył się znacznie i objął tak „egzotyczne” kwestie, jak rewitalizacja dzielnicy portowej w Buenos Aires, problemy z zachowaniem postsowieckiego przemysłowego dziedzictwa w Estonii czy problematyka rewitalizacji dzielnicy portowej Szczecina (prof. Piotr Fiuk) oraz funkcjonowanie starych elektrowni we Wrocławiu (prof. Marzanna Jagiełło, dr Bogusław Wowrzeczka). Następnie pojawiła się tematyka znacznie bliższa - był to blok „Doświadczenia łódzkie. Architektura, urbanistyka i sztuka w procesie przemian” poprowadzony przez dr Katję Bernhardt. Zaprezentowano przy tym bardzo różne doświadczenia: zarówno związane z budowlami przemysłowymi, jak i rezydencjami fabrykanckimi, ale też dotyczące tego, co było esencją łódzkiego przemysłu, czyli tkanin produkowanych w fabrykach włókienniczych. Wiele interesującego materiału, dotyczącego choćby wykorzystania technik komputerowych w kwestii rewitalizacji, przyniósł blok komunikatów, poprowadzony przez prof. Małgorzatę Omilanowską.

Dodać trzeba, że obradom towarzyszyły dyskusje, często pełne emocji, zaś szczególnie interesującym momentem była debata końcowa, która skupiła się na relacjach między służbami konserwatorskimi a kapitałem prywatnym. Każdy z biorących udział w wymianie zdań przywoływał przykłady ze znanego sobie obszaru geograficznego i odnoszące się do własnych zainteresowań badawczych bądź praktyki zawodowej. Nie zabrakło również refleksji ogólniejszych. Obrady naukowej części konferencji podsumował piszący niniejsze słowa, a dyrektor Centralnego Muzeum 


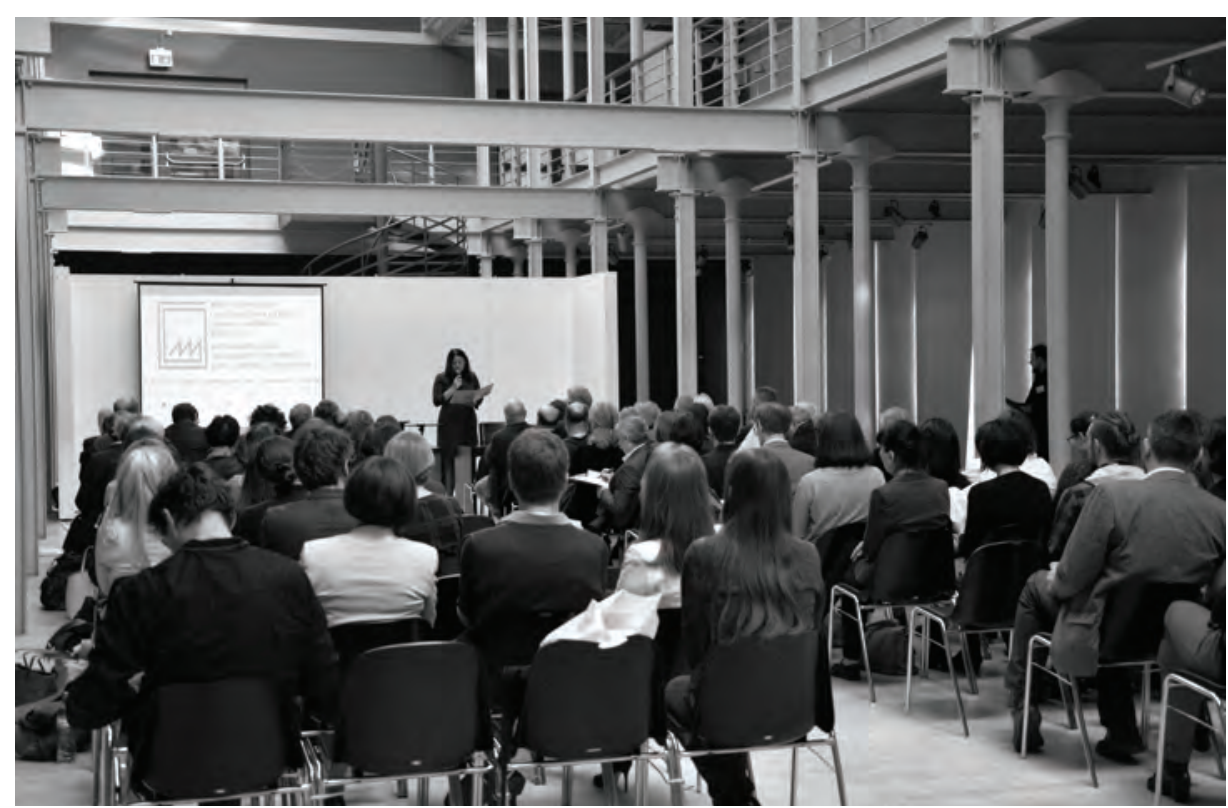

4. Wystąpienie powitalne dyrektor Centralnego Muzeum Włókiennictwa w Łodzi - Anety Dalbiak Fot. ze zbiorów Centralnego Muzeum Włókiennictwa w Łodzi

Włókiennictwa Aneta Dalbiak oficjalnie pożegnała zgromadzonych. W imieniu Grupy Roboczej Polskich i Niemieckich Historyków Sztuki i Konserwatorów głos zabrała dr hab. Beate Störtkuhl. Na tym zakończono merytoryczną część konferencji.

Ciekawym uzupełnieniem obrad było oprowadzenie gości po zabytkowym gmachu Centralnego Muzeum Włókiennictwa oraz prezentacja jego zbiorów i dorobku naukowego. Wieczór zaś wypełniło spotkanie towarzyskie w lokalu urządzonym w jednym z dawnych gmachów fabrycznych, które pozwoliło na lepsze poznanie się polskich i niemieckich uczestników konferencji.

Ostatni dzień, sobotę, przeznaczono na prezentację najciekawszych łódzkich osiągnięć w zakresie rewitalizacji i renowacji obiektów z epoki przemysłowego rozwoju miasta. Na trasie objazdu znalazł się kompleks Politechniki Łódzkiej, z poddanymi adaptacji gmachami fabryki Wilhelma Schweikerta (oprowadzanie: Aleksandra Sztuka z biura Miejskiego Konserwatora Zabytków), Księży Młyn, jeden z największych w Europie kompleksów przemysłu włókienniczego (po którym oprowadził Arkadiusz Bogusławski, pełnomocnik Urzędu Miasta Łodzi ds. Rewitalizacji zespołu Księżego Młyna), a następnie poddany adaptacji zespół dawnej łódzkiej elektrociepłowni. Zwieńczeniem było zwiedzanie Muzeum Miasta Łodzi, mieszczącego się w dawnym pałacu Izraela Poznańskiego, a następnie centrum handlowo-rozrywkowego Manufaktura, powstałego w wyniku przebudowy dawnych zakładów włókienniczych tegoż fabrykanta. Objazd był ważnym dopełnieniem wysłuchanych podczas dwudniowej sesji referatów, szczególnie tych dotyczących tematyki lokalnej. Końcowym akcentem międzynarodowego spotkania był obiad w restauracji mieszczącej się w zabytkowym gmachu dawnej fabryki Poznańskiego. 


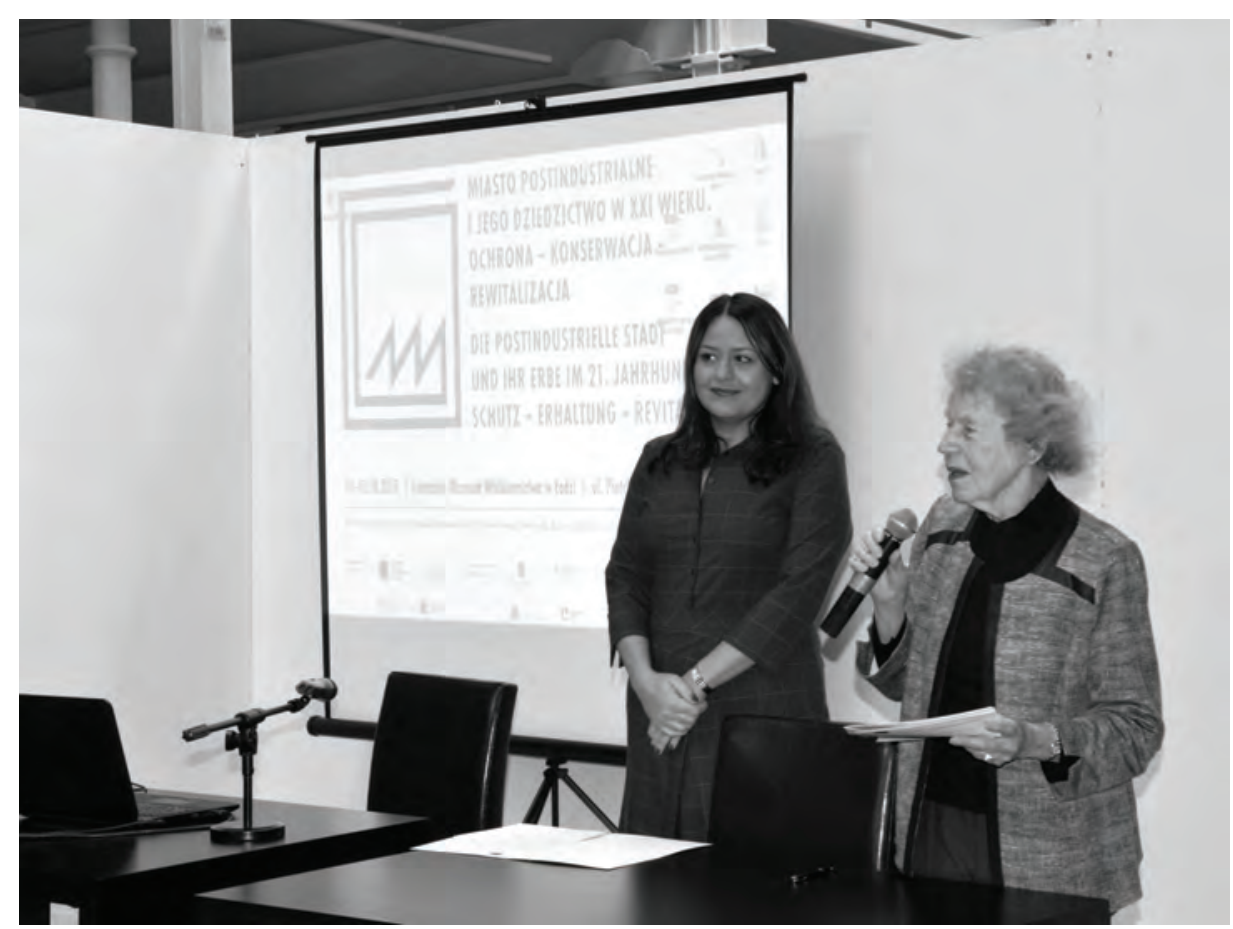

5. Wystąpienie prof. Ewy Chojeckiej, profesor emerytowanej Uniwersytetu Śląskiego w Katowicach, obok dyrektor Centralnego Muzeum Włókiennictwa w Łodzi Aneta Dalbiak Fot. ze zbiorów Centralnego Muzeum Włókiennictwa $w$ Łodzi

Wśród uczestników łódzkiej konferencji znaleźli się przedstawiciele najważniejszych ośrodków naukowych z Niemiec i Polski, ale również ze Szwajcarii i Estonii. Byli to zarówno uznani badacze o bogatym dorobku, jak i młodzi naukowcy u progu swojej kariery. Z wystąpieniami wykładowców akademickich sąsiadowały referaty przygotowane przez urzędników i muzealników, dzięki czemu ujęcie tematyki obrad odznaczało się daleko idącą interdyscyplinarnością i szeroką perspektywą porównawczą.

Obrady konferencji „Miasto postindustrialne i jego dziedzictwo w XXI wieku. Ochrona - konserwacja - rewitalizacja” dzięki różnorodności ujęć i dobranych przykładów w obrębie zakreślonego obszaru tematycznego pozwoliły uczestnikom na poszerzenie horyzontów, zapoznanie się z nowymi rozwiązaniami i tendencjami. Stworzyły, podobnie jak to było podczas poprzednich spotkań firmowanych przez Grupę Roboczą, platformę współpracy między specjalistami z Polski i Niemiec. Swoją satysfakcję z przyjazdu do Łodzi i udziału w konferencji podkreślało w prywatnych rozmowach wielu jej uczestników. Niezależnie od rezultatów merytorycznych, była to znakomita promocja Łodzi jako miasta, które podjęło wielkie wyzwanie, jakim jest rewitalizacja dziedzictwa przemysłowego i gdzie realizowanych jest wiele nieszablonowych projektów. 


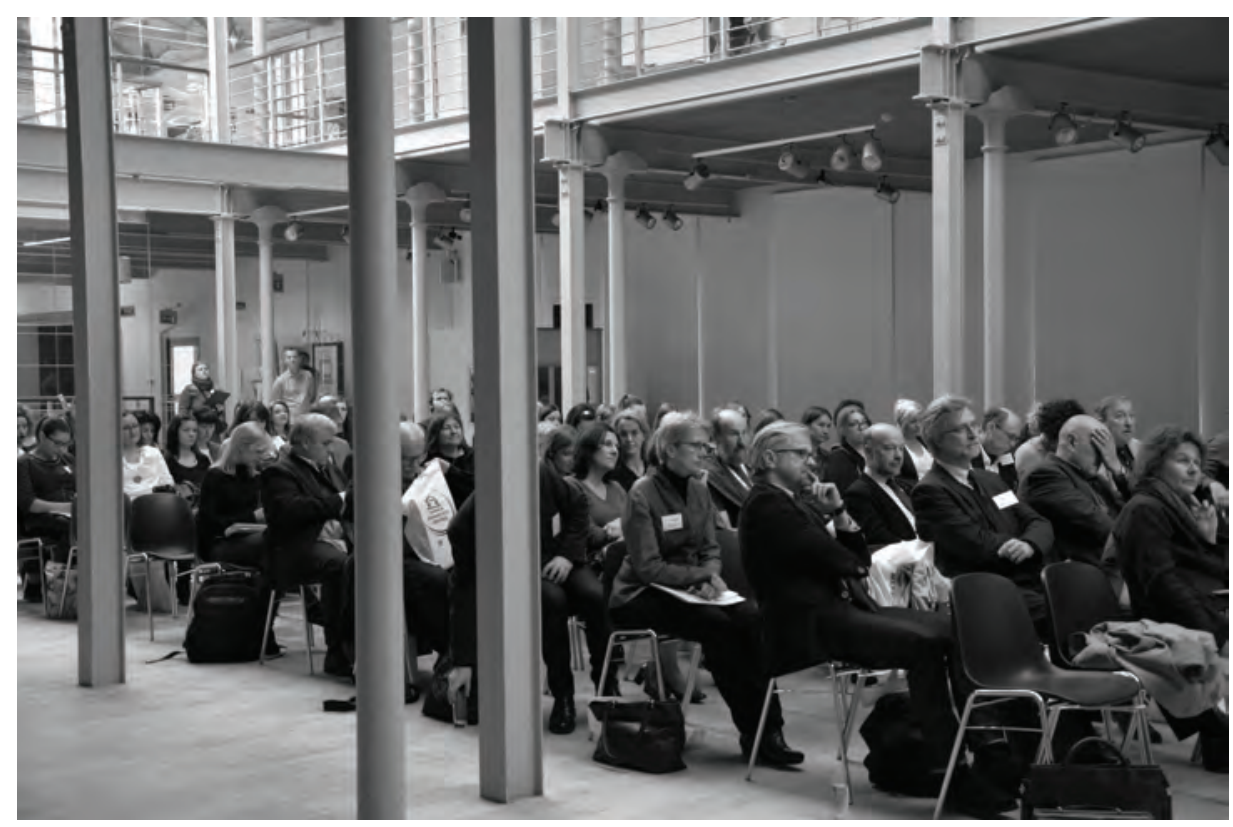

6. Uczestnicy konferencji podczas obrad. Fot. ze zbiorów Centralnego Muzeum Włókiennictwa w Łodzi

Na sukces 25. Konferencji Grupy Roboczej Polskich i Niemieckich Historyków Sztuki i Konserwatorów złożył się wysiłek wielu osób, przede wszystkim związanych z Centralnym Muzeum Włókiennictwa w Łodzi. Oprócz dyrektor Anety Dalbiak trzeba wymienić w tym miejscu Jerzego Głowackiego, Beatę Bocian, Olgę Tuszyńską-Szczepaniak, Michała Sierbę, Katarzynę Witas. Przygotowanie merytorycznego programu pozostawało głównie w gestii pracowników Katedry Historii Sztuki Uniwersytetu Łódzkiego (prof. Krzysztof Stefański, prof. Piotr Gryglewski, mgr Alina Barczyk) oraz członków Oddziału Łódzkiego Stowarzyszenia Historyków Sztuki (dr Łukasz Sadowski, dr Karolina Stanilewicz). Obecnie trwają prace nad przygotowaniem publikacji pokonferencyjnej ${ }^{1}$.

\footnotetext{
W tekście wykorzystano Sprawozdanie z 25. Konferencji Grupy Roboczej Polskich i Niemieckich Historyków Sztuki i Konserwatorów „Miasto postindustrialne i jego dziedzictwo w XXI wieku. Ochrona - konserwacja - rewitalizacja" autorstwa mgra Jerzego Głowackiego z Centralnego Muzeum Włókiennictwa w Łodzi.
} 